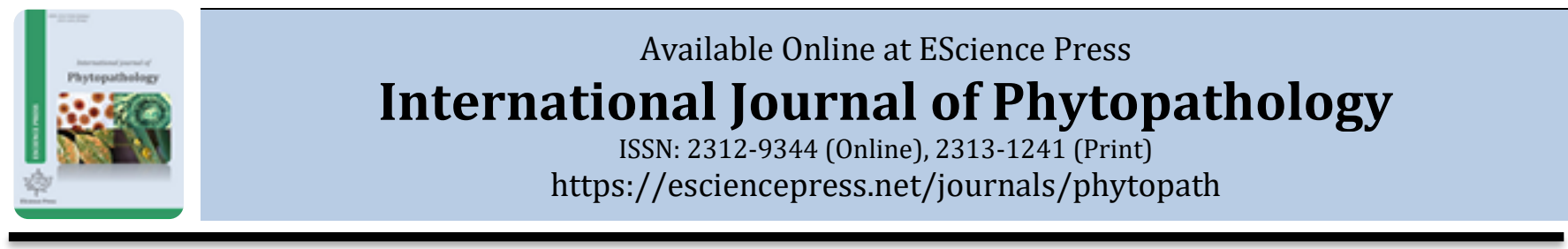

Disease Note

\title{
FIRST REPORT OF CANDIDATUS PHYTOPLASMA PRUNORUM, THE EUROPEAN STONE FRUIT YELLOWS PHYTOPLASMA ON PEACH TREES ON THE TERRITORY OF CANTON OF GENEVA, SWITZERLAND
}

\author{
Aneliya Etropolska, François Lefort* \\ Jussy, Geneva, Switzerland. \\ *Corresponding Author (François Lefort) Email: francois.lefort@hesge.ch
}

Plants and pathogens group, Institute land Nature Environment (inTNE), School of Architecture Engineering and Landscape (HEPIA), HES-SO University of Applied Sciences and Arts Western Switzerland, Route de Presinge 150, 1254

A B S T R A C T

In recent years, 'Ca. P. prunorum', the agent of ESFY was reported from several apricot orchards of Canton of Wallis, the main apricot production region in Switzerland (Genini and Ramel, 2004). The psyllid vector Cacopsylla pruni was also found in several locations in the Lake Geneva area (Ackermann et al., 2006). The presence of the disease and of its proven vector $C$. pruni at the eastern part of the Lake Geneva area, as well as the existing risk of dissemination of ESFY to other stone fruit orchards along the Lake Geneva are the reasons for which ESFY needs to be studied further. ESFY and its possible dissemination through C. pruni on the territory of Canton of Geneva, bordering France, has never been yet studied. In 2016, visual observations were conducted in several stone fruit orchards near Geneva. Plant material was obtained from peach trees, displaying some of the typical symptoms such premature leaf colouration, leaf-roll, tree decline (Sabate et al., 2015), in the autumn, when the concentration of the phytoplasma in the upper parts of the trees is the highest. Phloem was prepared from branches and was extracted with a CTAB-based adapted protocol (Lefort and Douglas, 1999). PCR amplification of phytoplasma DNA was achieved with the universal primers: fP1/rP7 (Deng and Hiruki, 1991; Schneider et al., 1995). All positive samples were tested with the ESFY-specific non-ribosomal primers ECA1/ECA2 (Jarausch et al., 1998). Typical symptoms of ESFY, like premature leaf colouration, leaf yellowing with reddish edges, leaf-roll, severe chlorosis, die-back of top branches and partial or, complete decline of the trees (Figure 1) were found in a peach orchard (GPS coordinates: $46^{\circ} 15^{\prime} 17.4^{\prime \prime} 6^{\circ} 12^{\prime} 40.7^{\prime \prime E}$ ) located in the area of Collonge-Bellerive, close to Geneva city. Ten trees were sampled in this orchard. The presence of ' $\mathrm{Ca}$. P. prunorum' was confirmed in two of them (Figure 2 and Figure 3). At the beginning of spring 2017, the monitoring of the ESFY symptoms in the infested orchard was resumed. Early bud break was found on the two infected trees and the infection was confirmed again by PCR (Figure 4 and Figure 5). The same symptoms were observed in many trees of this orchard, which correlated with the previous autumn observations. Trapping confirmed the presence of the insect vector Cacopsylla pruni (Bodnár et al., 2018) in the infected area. In order to understand more about the origin and the diversity of ESFY phytoplasma in this area, additional plant and insect samples will be analyzed. The correlation between symptoms and infected plants will be studied further. We report here for the first time on the occurrence of 'Candidatus Phytoplasma prunorum' ('Ca. P. prunorum') the agent of ESFY on the territory of Canton of Geneva.

Keywords: Rhizopus stolonifer, grapes, Rhizopus bunch rot, ITS region, pathogenicity.

\section{ACKNOWLEDGEMENTS}

We would like to thank Julien Crovadore, Bastien Cochard, Romain Chablais (hepia) for their technical support and especially Dr. Wolfgang Jarausch (AIPlanta Agroscience - Germany), who kindly provided us the ESFY positive controls. 


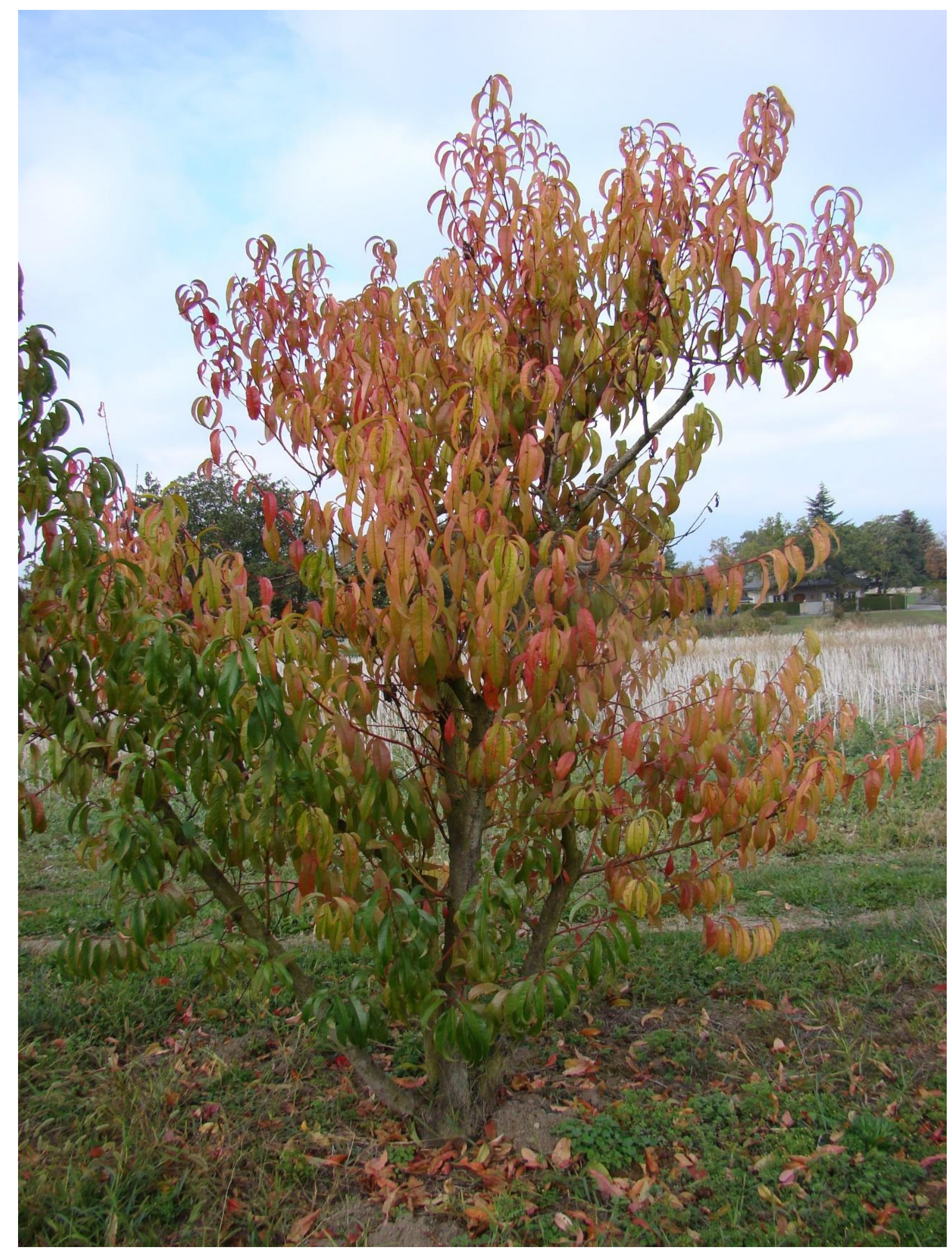

Figure 1. ESFY symptoms on peach trees in early autumn, in which infection was later confirmed: leaf yellowing with reddish edges, leaf reddening, leaf-roll and dieback of some branches. 


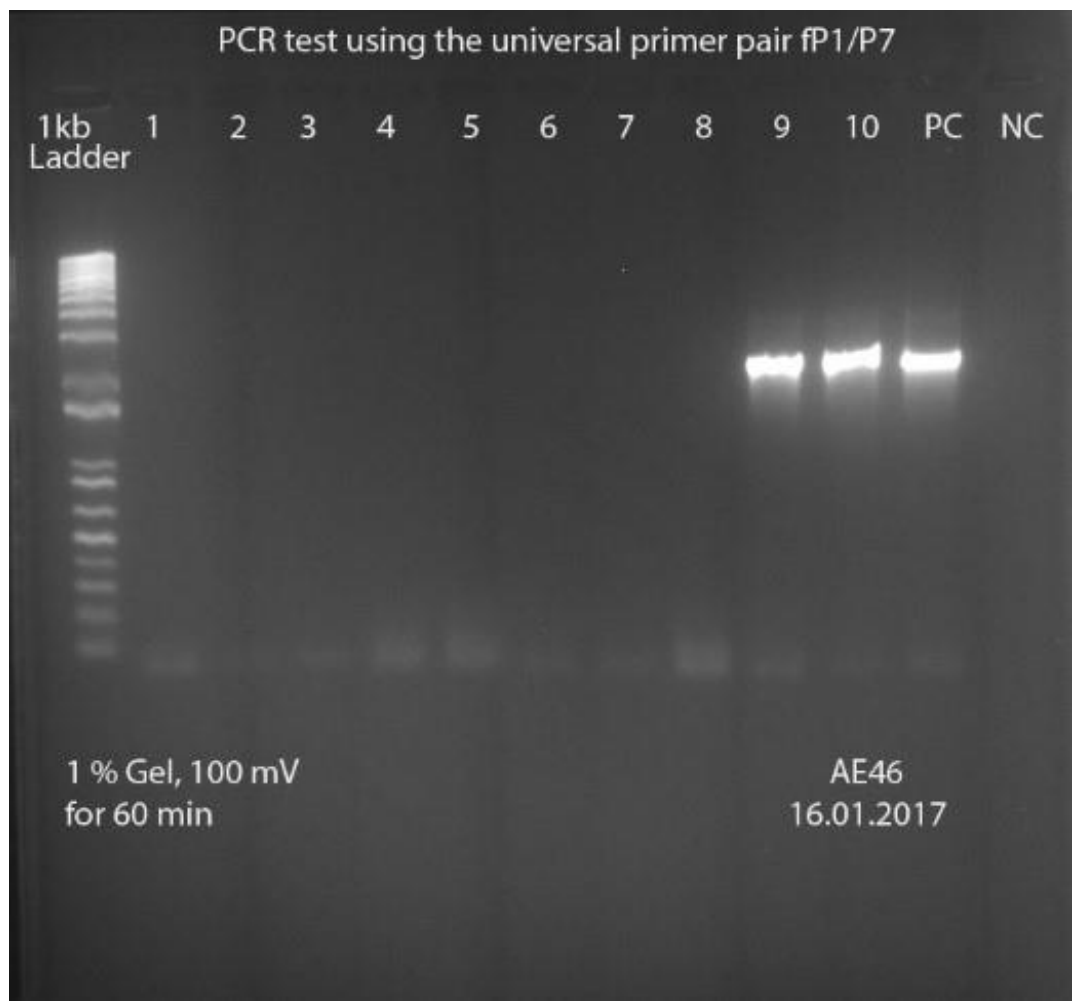

Figure 2. Electrophoregram of a PCR amplification with universal primers fP1/P7 (1-10: peach tree samples, NC: negative control, PC: positive control ESFY strain I1).

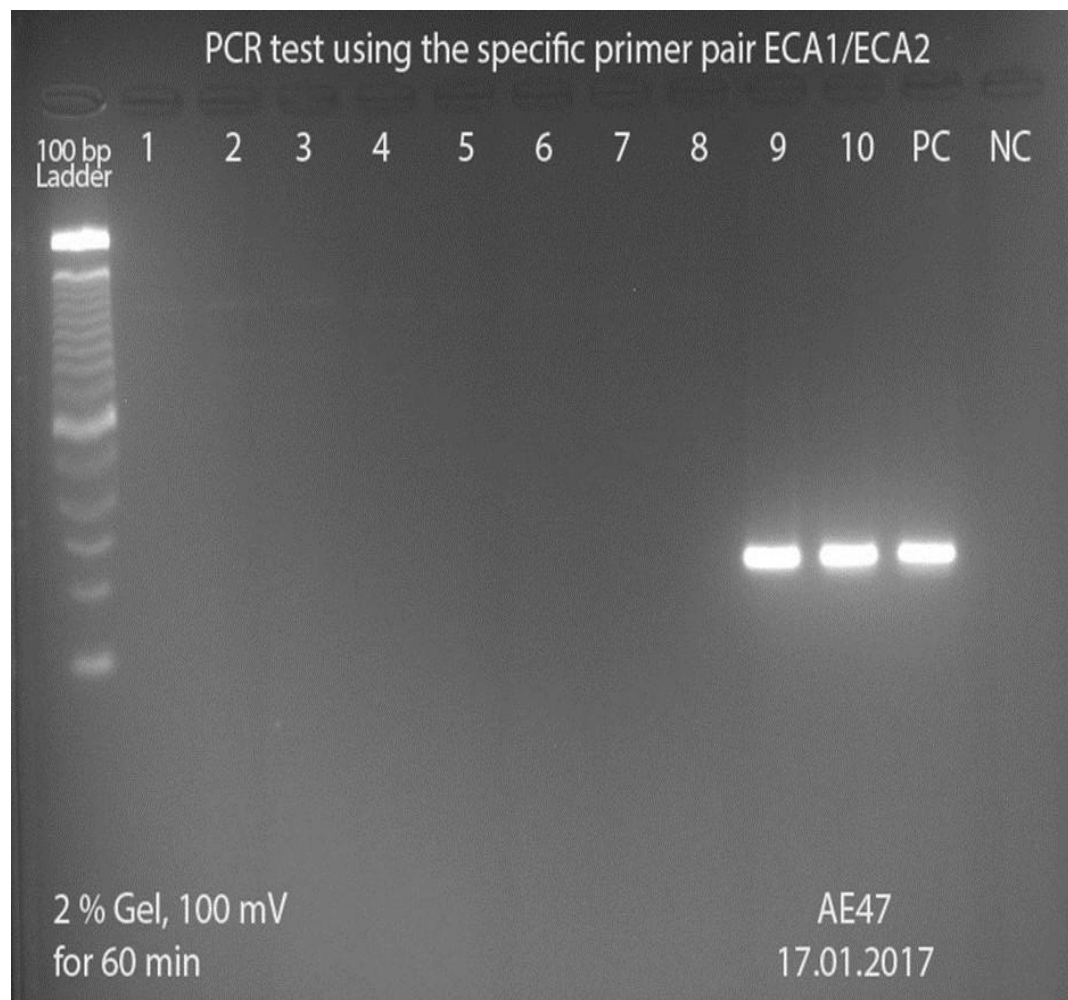

Figure 3. Electrophoregram of a PCR amplification with ESFY-specific primers ECA1/ECA2 (1-10: peach tree samples, NC: negative control, PC: positive control ESFY strain I1). 


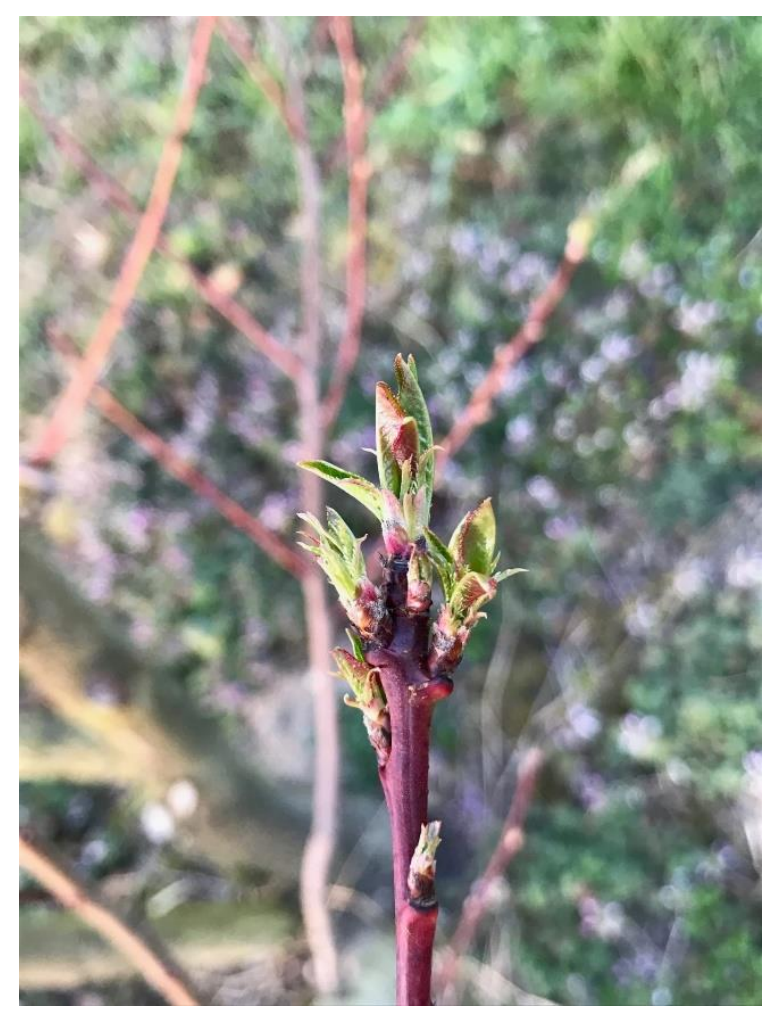

Figure 4. General view of ESFY symptoms on an infected peach tree, observed at the beginning of April 2017: Early bud break, reddening of the twig bark.

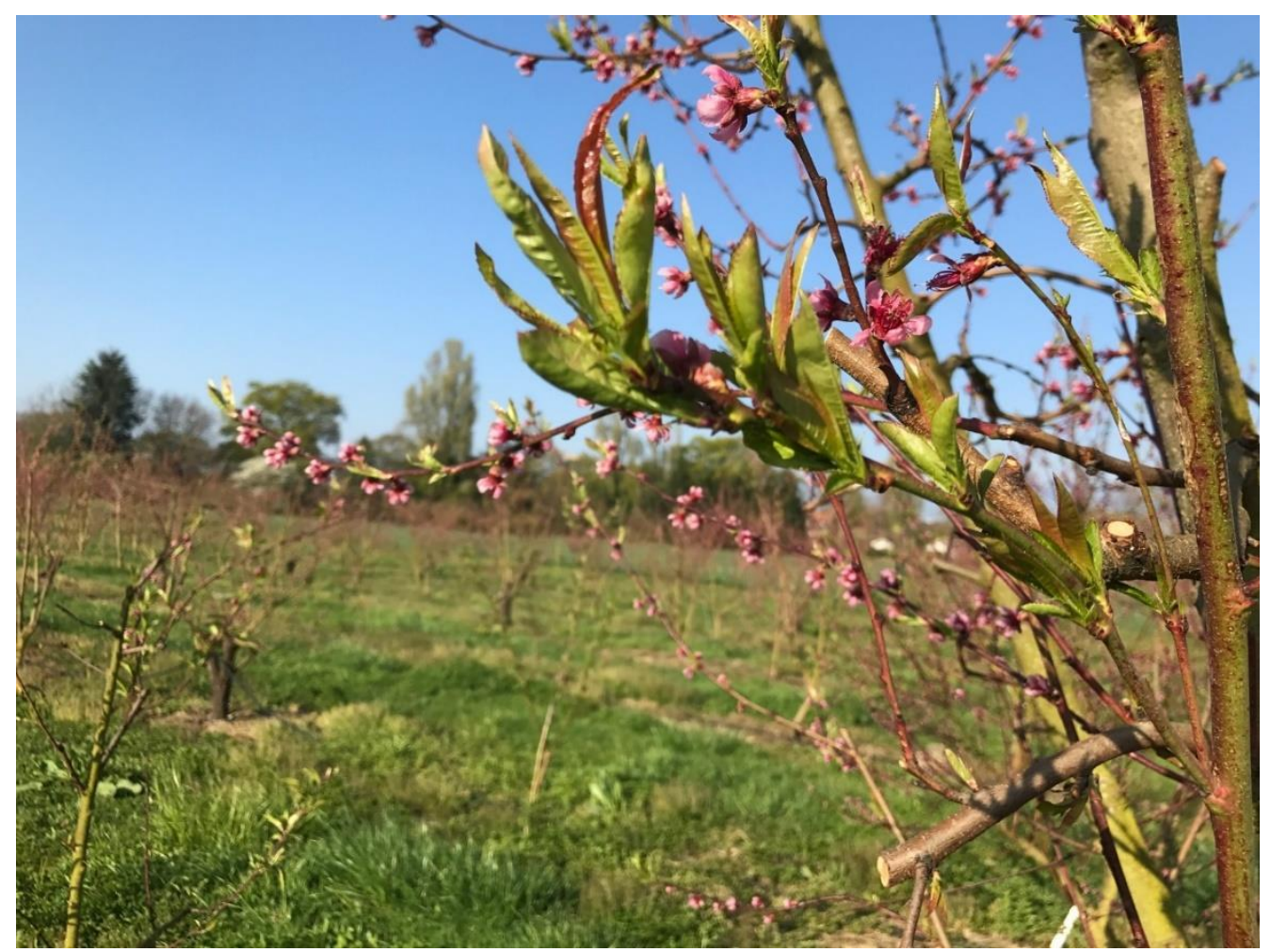

Figure 5. ESFY symptoms on twigs of an infected peach tree, observed at the beginning of April 2017: Premature leaf coloration, leaf-roll. 


\section{REFERENCES}

Ackermann, T., H. Höhn and M. Bünter. 2006. Europäische Steinobst-Vergilbungskrankheit (ESFY)-Überwachung 2006 in der Schweiz, 22: 8-11.

Bodnár, D., K. Csüllög and G. J. A. A. D. Tarcali. 2018. Review of the biology of plant psyllid (Cacopsylla pruni, Scopoli 1763), and its role in the spreading of European stone fruit yellows, ESFY-phytoplasma with Hungarian data. Acta Agraria Debreceniensis: 25-33. https://doi.org/10.34101/actaagrar/74/1660

Deng, S. and C. Hiruki. 1991. Amplification of 16S rRNA genes from culturable and nonculturable mollicutes. Journal of Microbiological Methods, 14: 53-61. https://doi.org/10.1016/0167-7012(91)90007-D

Genini, M. and M. E. Ramel. 2004. Distribution of European stone fruit yellows phytoplasma in apricot trees in Western Switzerland XIX International Symposium on Virus and Virus-like Diseases of Temperate Fruit Crops - Fruit Tree Diseases. International Society for Horticultural Science. pp. 455-58.

Jarausch, W., M. Lansac, C. Saillard, J. M. Broquaire and F. Dosba. 1998. PCR assay for specific detection of European stone fruit yellows phytoplasmas and its use for epidemiological studies in France. European Journal of Plant Pathology, 104: 17-27. https://doi.org/10.1023/A:1008600828144

Lefort, F. and G. C. Douglas. 1999. An efficient micro-method of DNA isolation from mature leaves of four hardwood tree species Acer, Fraxinus, Prunus and Quercus. Annals of Forest Science, 56: 259-63. https://doi.org/10.1051/forest:19990308

Sabaté, J., A. Laviña and A. Batlle. 2015. Incidence and distribution of 'Candidatus Phytoplasma prunorum'and its vector Cacopsylla pruni in Spain: an approach to the epidemiology of the disease and the role of wild Prunus. Plant Pathology, 65: 837-46. https://doi.org/10.1111/ppa.12464

Schneider, B., E. Seemüller, C. D. Smart and B. C. Kirkpatrick. 1995. Phylogenetic classification of plant pathogenic mycoplasma-like organisms or phytoplasmas. In: S Razin and J C Tully (eds.), Molecular and Diagnostic Procedures in Mycoplasmology Academic Press Inc.: San Diego, California, USA. https://doi.org/10.1016/b978-012583805-4/50040-6

Publisher's note: EScience Press remains neutral with regard to jurisdictional claims in published maps and institutional affiliations.

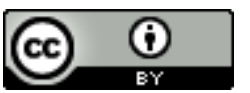

Open Access This article is licensed under a Creative Commons Attribution 4.0 International License, which permits use, sharing, adaptation, distribution and reproduction in any medium or format, as long as you give appropriate credit to the original author(s) and the source, provide a link to the Creative Commons license and indicate if changes were made. The images or other third-party material in this article are included in the article's Creative Commons license, unless indicated otherwise in a credit line to the material. If material is not included in the article's Creative Commons license and your intended use is not permitted by statutory regulation or exceeds the permitted use, you will need to obtain permission directly from the copyright holder. To view a copy of this license, visit http://creativecommons.org/licenses/by/4.0/.

(C) The Author(s) 2019. 